\title{
Karl Barth's male-female order: A kingpin of dogmatic disparity
}

\author{
Yolanda Dreyer \\ Department of Practical Theology \\ University of Pretoria
}

\begin{abstract}
Karl Barth's gender perspective is often analysed with reference to his so-called "theoethics" or "creational theology". This perspective perpetuates an asymmetry in gender relations that was prevalent in Biblical times, throughout Christianity and to some extent still is visible today. He based his view on the subordination of women on an exegesis of Genesis 1:27 as "intertext" of Ephesians 5:22-23. Barth's asymmetrical gender perspective is a product of his embedment in Western Christian tradition which in turn, is rooted in early Christian patriarchal theology. The aim of this article is to focus on Barth's ontological reframing of the traditional understanding of the Biblical notion of human beings as created in the "image of God". The article consists of four sections: (a) Luther's and Calvin's gender perspectives; (b) the Enlightenment failure to achieve emancipation; (c) gender disparity in Reformed theology; and (d) a feminist alternative.
\end{abstract}

\section{INTRODUCTION}

Karl Barth's ( $C D$ III.4.6) gender perspective is often analysed with reference to his so-called "special ethics" (e g McKelway 1979:345-357; Ford 1984). In a preceding article I investigated Barth's interpretation of the Biblical notion of the "subordination" of women. It was done from an ethical perspective (Dreyer 2007). I argued that Barth did not succeed in escaping the trap of asymmetry in gender relations, which was prevalent in Biblical times, throughout Christianity and is still, to an extent, visible today. Barth based his interpretation on an "exegesis" of Genesis 1:27 as "intertext" of Ephesians 5:22-23. The preceding article aimed to show that Barth's asymmetrical gender perspective should be seen as a product of his embeddedness in Western Christian tradition which, in turn, is rooted in early Christian patriarchal theology. Building on the previous, I focus in this article on Barth's ontological reframing of the traditional understanding of the Biblical notion of 
human beings as created in the "image of God" (Barth, $C D$ 1.1; see translation by Bromiley et al [1975:238-239]).

For decades theologians (e g Berkouwer 1962; Ford 1984; Hart 2000:41-44; Dawson 2007:29, 49) have been investigating how Barth replaced the "fixed" ontological understanding of God's self-revelation in Christ as the incarnated Word, with a more "flexible" analogical understanding which is in line with Paul's analogia fidei (Rom 12:6). ${ }^{1}$ From the dialectic between "divine speaking" (Deus dixit) and "human knowing in the act of faith" (McCormack 1998:18-37), Barth explains the relationship between men and women who live in the presence of God, as an analogia relationis. On this point Barth moves away from the traditional view (see my previous article Dreyer 2007:1493-1521). Though Barth "de-ontologises" the traditional understanding of the relationship between God and human beings, he does retain the traditional Christian belief when it comes to the "subordination" of women. Feminist theologians would obviously protest such a view (cf e g Bird 1991; Børresen 1991a, 1991b).

The aim of this article is to argue from a feminist gender perspective that Barth's heritage of Reformed theology could well be the cause of this view, which is illustrated in his clash with Schleiermacher (see inter alia Barth [1952] 1973:425-473; 1978:117-135; [1923-1924] 1982; cf Crouter 2005:172). Where Barth's "theoethichs" with regard to the subordination of women was the product of how he had absorbed early Christian tradition, his gender asymmetry can be seen as a product of "dogmatic disparity" caused by his adherence to an outdated Reformed "revelation-based theology" (cf Wallace 1995:114).

\section{PREMISE}

Barth discusses his concept of analogia relationis in the third volume of his Church Dogmatics. This analogy is central to his doctrine of creation which is illustrated by the male-female relationship (Ford 1984:5). The older concept of analogia entis which dominated classical theology prior to Karl Barth, is the idea that there is a "common ground of being" between God and creation (Ford 1984:5). Such an ontological premise implies that human beings are able to understand God. However, according to Barth's (1934-1964:241-242) theology of God as the wholly Other, it is not possible for human beings to understand God through their experience. He puts it as follows:

\footnotetext{
${ }^{1}$ Bruce McCormack (1998:11 note 33) formulates Barth's view on analogia fidei as follows: "an analogical relation between divine speaking in the act of revelation and human knowing in the act of faith".
} 
Let us hold on to the fact that faith is experience, a concrete, fixable, temporal act of this man's or that, the act, in short, of acknowledgement. But it does not go without saying that experience is real experience, experience of the Word of God. Of no experience as such, however perfect a form it may have, could this be said. Therefore it is not as experience that faith is faith, i.e. real experience, although it is certainly experience.

One of the first theologians who reflected exhaustively on Barth's adaptation of classic ontology was the Dutch professor in dogmatics, G C Berkouwer (1962). According to Berkhouwer (1962:48), both Lutheran and Reformed theology were very careful when stating that human beings "in some sense" retained something of the image of God after the Fall. In Eastern Orthodox theology, on the other hand, the image of God is seen as "the ens realissimum of man, the basic essence, the permanent and indestructible divine ground of his existence" (Bulgakov 1937:223). For Bratsiotis (1951:289297 ) it is not the image of God in human beings that was corrupted by the Fall, but rather human nature itself. The essential aspect of God's image in human beings is love. Other aspects preserved in God's image in sinful human beings, are not only reason and freedom, but also a "yearning for God" and "a striving for good". Human beings retain their freedom, though this is weakened by sin, and they are "capable, despite the darkening of [their] understanding, of seeking the truth and partially finding it" (Verkhowsky $1951: 321,323)$. From a Protestant "orthodox" view, Berkhouwer's (1962:51) critical response to Eastern Orthodox theology is that the Bible does not present human beings in "this isolated ontic aspect". The whole human being exists in God's presence and is judged by God. The Bible is interested in what human beings are and do in the totality of their existence.

However, not all Protestant theologians concur with Berkhouwer (or Barth) in this respect. Emil Brunner, for example, sees the image of God in human beings as having two aspects: the formal and the material. The formal image is that which cannot be lost, which is not affected by the contrast between sin and faith (see Brunner [1963]). The material image, on the other hand, is about how a person obeys the Word of God. The original righteousness was lost with the Fall, but renewed again by Jesus Christ and can be appropriated by human beings by means of salvation. In spite of the fall, human beings therefore remain human and carry within them two basically different aspects of the image of God (cf Brunner 1952, 1957, [1957] 1965, [1963] 1984).

According to Berkouwer (1962:52), in every discussion of the image of God two questions keep surfacing. One concerns the humanitas of human 
beings. What makes them human in spite of their fallen state? The other concerns the relationship of this fallen humanity with the image of God. How can a fallen human being still reflect the image of God? Berkhouwer (1962:53) poses the question: "Do we not, then, in dealing with an image which is both kept and lost, have to do with a strange paradox, or a dialectic, or a mysterious antinomy, which invites confusion?"

For Luther (see Buitendag 2007:445-461), the most important part of the image of God in human beings is that part with which people respond to God by loving and glorifying God. According to Berkhouwer (1962:57), those who see the image in people's response to God and service to God, do not deny the humanity of sinful human beings. Berkhouwer (1962:58) considers the question whether Scripture gives any indication of an analogy, an analogia entis, an analogy of being between God and human beings, some aspect of humanity that could not be destroyed - not even by the Fall.

Earlier theologians such as Origenes (De Principiis, III.IV.1, ed by Görgemanns \& Karpp 1976:462-560, 668-764) distinguish between the "image" and "likeness" in order to indicate that human beings did "receive the dignity of the image, but that its fulfillment in the likeness was reserved for the future and is reached through works and exertion" (Berkhouwer 1962:68). Because of the use of the two terms tselem ("image") and demuth ("likeness") the exegete could be led to think that they refer to two different concepts. However, this line of thought was already broken by Luther and Calvin. In orthodox Reformed theology the terms were seen as interchangeable (see see the dogmatics of, among others, Herman Bavinck 1906-1910). For Calvin (Institutes I.XV.3; with regard to Gen 1:26, see also Calvin, J [1948], Commentaries on the First Book of Moses called Genesis), "image" and "likeness" simply reflected the Hebrew use of parallelism. According to Berkhouwer (1962:69) the way in which the terms are used in Genesis also indicates that their meaning is the same.

As to the content of the image of God in human beings, Barth sees dominium as a consequence of the image rather than as an inherent characteristic. For him the content of the image is analogia relationis rather than analogia entis. The image of God is created in human beings, man and in woman. According to Barth (CD III.1.207-220), Genesis 1:27 emphasises the difference between men and women - difference means that the entities relate to one another in a certain way. The relation between God and human beings is reflected in the relationship between man and woman, which in turn provides the content of the image of God in men and women, namely relationship. 
However, Berkhouwer (1962:73) disagrees with Barth on this point: "But this does not necessarily mean that the second clause gives a definition to the first; it does not necessarily imply that the image of God lies in the relationship between man and woman." Berkhouwer (1962:73-74) agrees with Barth that man and woman are important for creation, but he disagrees with Barth's further conclusion that the relationship between man and woman provides the specific content of the image, especially since other Scriptural references to the image of God make no mention of this relationship. Berkhouwer (1962:73) points out that, when Barth refers specifically to Genesis, he emphasises the relationship between man and woman, but when he speaks more generally of the analogia relationis, the emphasis is rather on the relationship of "man" to "men", meaning the relationships among human beings. Barth (CD III.1.225) refers to the man-woman relationship as a general human relationship "in its most original and concrete form".

Berkhouwer (1962:73) criticizes this as an unresolved ambiguity: "Barth holds, then, to both constructions: the man-woman relation because the text demands it, and the man-fellow-man relation because it is implied in analogia relationis." He is of the opinion that what Barth presents as a "straight forward defining explanation of the text" is rather "constructive interpretation" (Berkhouwer 1962:73). If the content of the image of God cannot be satisfactorily described as either dominium or analogia relationis, what would it then be?

Not all attempts to solve this mystery did so by means of exegesis of passages of Scripture. Some sought the content of the image of God in anthropological categories, for example the Old Testament theologian Walter Eichrodt ([1939] 1967:62; cf [1939] 1961) for whom the content of the image of God manifests in the "spiritual superiority" of human beings and in their "self-consciousness and personality". For Von Rad (1964:381-383; [1953] 1972 / [1961] 1972), another Old Testament scholar, the image of God can be seen in human beings in a concrete visible way (cf Von Rad [1961] 1972). The whole person (including the body) was made in the image of God.

Berkhouwer (1962:75) comments on the traditional tendency to exclude the human body and all bodily functions from the image of God, which could only reside in the "higher qualities" of human beings. This view was rejected when the dualism between body and soul was transcended and human beings were again seen as whole persons. No support can be found in Scripture for dividing human beings into body and soul.

Which choice one makes regarding the relationship between body and soul, will profoundly affect the discussion of the image of God in human beings. According to Berkhouwer (1962:77), "Scripture's emphasis on the 
whole man as the image of God has triumphed time and time again over all objections and opposing principles. Scripture does not make a distinction between man's spiritual and bodily attributes in order to limit the image of God to the spiritual, as furnishing the only possible analogy between man and God." Old Testament exegete Walther Zimmerli ([1907] 1967; in Berkhouwer 1962:79) points out that the difference between what is spiritual and therefore not visible, and that which is material and visible, comes from idealistic philosophy rather than from the Bible. The second commandment does not endeavour to protect God's transcendence against anthropomorphism. Rather, portrayal of God in anthropomorphic terms is part and parcel of the Biblical message. It is specifically by means of these descriptions that God's attitudes and actions are shown to human beings (Berkhouwer 1962:81). According to Zimmerli (in Berkhouwer 1962:81): "Jahwe does not scorn the visible; [God] deals with Israel through it; but [God] does scorn those who would attempt to hold God captive, in images in this visible world."

For Barth (CD III.2.143) the only way to know human beings is through Christ. Attempts at self-understanding are useless. The sciences that try to understand human being better, do have value, but their value is limited. They cannot shed light on "real" humanity. This can only be known through and by means of God's revelation in Jesus of Nazareth. Humanity exists in God's grace. This is the essence of being human - an essence which could not be destroyed by sin. What remains is a "continuum, an essence unchanged and unchangeable by sin" (Barth $C D$ III.2.43-50, 54-55). The essence of humanity can therefore only be discerned through Jesus, the man.

Barth proceeds to try and find this essence by searching for it in Jesus. What can be seen in him, can also be discerned in all other human beings. This does not mean that there is a direct similarity between sinful human nature and Jesus' human nature. Jesus is human nature without the "selfconflicts and contradictions" from which people suffer. He is the "original and archetypal" form of human nature (Barth CD III.2.58-60). This means that human nature cannot be described and then found back in Jesus. Jesus is the starting point from which human nature is to be understood. Berkhouwer (1962:92) calls this Barth's "Christological interpretation of man's nature".

If being in relationship with God is the nature of humanity, then human beings cannot turn away from God. If they were to do so, they would essentially lose their humanity. However, the essence of humanity is not lost because God does not let go of the relationship. Whatever their choices, human beings are preserved by God's grace (Barth CD III.2.161-162, 167, 175, 195-197, 201-229, 235, 330). As far as body and soul are concerned, Barth does not accept a dualistic anthropology where body and soul are 
separated. He also rejects the idea of an immortal rational spirit which is higher than the body. God created human beings as completely soul and completely body (Barth $C D$ III.2.440, 445-448, 471-472). This whole human being is totally dependent on God. The centre of this person is the heart: "We must say of the heart that it is, in the sense of the Biblical texts, the kernel of the whole man; not only the center of his activity, but its total content" (Bart CD III.2.520-523).

Berkhouwer (1962:95-96) points out that there is an inner tension in Barth's anthropology. On the one hand Jesus is the archetype (Urbild) of humanity and God's grace preserves the essence of humanity, and on the other hand human beings are totally dependent on the Creator. He also shows that Barth emphatically states that human beings participate in Jesus' nature, not Jesus in human nature, whereas the Bible describes how Jesus took on the form of humanity and became like human beings. For Barth, however, the essence of human beings is to exist in grace. Therefore Jesus does not participate in human nature, but humans participate in his nature.

It has become clear that Berkhouwer's view on women as the bearers of the image of God differs from Barth's unequal gender relations. As an orthodox Protestant theologian Berkhouwer, however, does not succeed in transcending the vestiges of inequality in the gender perspectives of Luther and Calvin.

\section{THE GENDER PERSPECTIVE OF LUTHER AND CALVIN}

The question as to the nature of woman was approached by Reformation theologians Luther and Calvin form the perspective of what "Scripture alone" had to say. Though they could not distance themselves completely from tradition, they did try to start afresh with the Bible itself. With their Renaissance knowledge of Greek, Hebrew and textual criticism, they did not make as much use of allegorical exposition as did the theologians of the Middle Ages (see Børresen 1981:26-29). There was also a greater interest in the historical context of the Bible (Douglass 1991:230). The emphasis on "Scripture alone" prevented the Reformers to speculate about women in the way that was done by Medieval scholasticism (cf Douglass 1985). From this new perspective "... wurde die Allegorese nur durch den Gesichtspunkt eingeschränkt, daß sie nichts zutage fördern dürfe, was nicht auch sonst direkt durch die Schrift belegt ist und zum Inhalt des christlichen Glaubens gehört" (Ebeling 1971:61; cf Oberman 1963:50-55; Bouwsma 1988:106-107, 157).

According to Luther, in his commentary on Genesis, Adam and Eve were both created in the image of God and therefore possessed special 
knowledge and abilities. This was lost during the "fall" of Adam and Eve, according to the Genesis story. The gospel message brings restoration of the image of God in human beings and with it the hope of eternal life. Restoration is not yet complete, but will be when the Kingdom of God comes (see Douglass 1991:231-232). Then the power of God's image in human beings will be renewed and they will be free from fear. They will rule over everything. Luther mostly refers to Adam and Eve together, but also mentions Eve separately: "Eve possessed these abilities in a way equal to Adam" and: "Therefore she not only heard these things from Adam, but her own nature was pure and full of the knowledge of God, so that by herself she understood and reflected on the word of God" (D Martin Luthers Werke, Weismar kritische Ausgabe $=$ WA 42, $50=$ Koffmane \& Reichert 1911:50, in Douglass 1991:233). For Luther, women also possess full human dignity. Luther rejects references to the Talmud about the first human as a being of both sexes, which later separated into male and female. He also rejects Aristotle's idea of woman as "deviant man" or "monster". In his commentary on Genesis 1:27 Luther states:

... it seems as though woman is a somewhat different being to man, because [anatomically] she is not the same and she has a weaker nature. Though Eve was a most extraordinary human being, equal to Adam because they were both created in the image of God, which means that they were equal in righteousness, wisdom and virtue, she still remained woman. Just as the sun is more extraordinary than the moon (though the moon is a most extraordinary entity), so woman, though an especially beautiful product of God, still does not equal the glory and dignity of the male.

(WA 42, 51-52, in Douglass 1991:134)

As indicated in the previous article (Dreyer 2007:1493-1521) Karl Barth elaborated in similar vein when explaining women's inferiority in spite of the restoration of women's dignity in and through Jesus Christ. For the Reformed theologians, women can be regarded as inferior because they are "weak" and therefore inclined to lead men into temptation. Satan approached Eve and not Adam because, though they were equally image of God, Adam was stronger and better than Eve. The serpent approached the weaker part of human nature (Douglass 1991:235).

Luther did not think that women should have official positions and function in the public sphere. He cited 1 Timothy 2:11 to justify his view. For him it is not about woman's inability. According to Luther, Paul [as author of 1 
Timothy - sic] thought that women could also be intelligent, but he was afraid that women would argue against their husbands in public (see, however, Köstenberger 1997:107-144). Luther pointed out that women in the Bible did have authority, but emphasises that those women were then unmarried (see Buitendag 2007:445-461). A married woman should not have authority over her husband. However, Luther nowhere entertains the notion that such an unmarried woman could have an official position (see Douglass 1991:241).

Calvin as a "second generation Reformer", could make use of the exegetical work of Luther and others. His education was also humanistic just as that of Luther. Calvin also deals directly with Scripture, not via Medieval theology and classical scholastic philosophy. He too struggles with the tension between Genesis 1 and 1 Corinthians 11 about the image of God and his solution was surprisingly "modern" (Douglass $1991: 243-245)$. In his Institutes he explains that Adam had good qualities, but lost them at the Fall. Christ paid for this and made eternal life possible for believers. Eve is not mentioned, since, as a man, Adam is representative of humanity. So Calvin renders woman invisible. A similar silence surrounds Eve's culpability regarding the Fall. The Institutes emphasise the unity of humanity and Calvin, like Barth, move away from the bodily inferiority of women as worked out by Aristotle and others. There is only one reference to woman's subordination in the Institutes. This is in connection with a discussion of bad rulers. Calvin urges that people should obey authorities in spite of the fact that rulers may be wrong at times. According to Calvin, dominance is simply a male prerogative - "the way it is". He does not give a theological reason for this. The "image of God" in human beings can be seen in their perfection before the Fall. Karl Barth tries to retain this idea of "perfection" when he refers to God's recreation in and through Jesus Christ. However, he perpetuates Calvin's view on women's subordination by retaining a "relational" disparity between male and female.

As was previously indicated, Calvin treats the terms "image" and "likeness" as equivalent Hebrew words. The image of God resides in the soul of human beings. Since the Fall it is difficult to see the image of God in broken human nature. Therefore it should be seen "in Christ", the second Adam, who restored the integrity of humanity and God's image in human beings. The fact that women's bodies are different does not mean that they cannot be the image of God, since this image is a spiritual matter (Douglass 1991:246). Calvin's (Inst 6.33) interpretation of 1 Corinthians 11 is worth mentioning. In 1536 he writes that the matters mentioned in 1 Corinthians are not essential, but should be seen as customs. 
Is religion to be found in the shawl of a woman, so that she sins when she leaves her house without covering her head? Is that injunction of Paul that women should be quiet [1 Cor 14:34] so holy that it may not be broken, lest it be seen as a serious transgression? ... Not at all ... let the customs of the region, human dignity itself and the rule of virtue dictate what should be done or avoided.

Reformed theologians often regarded the matter of a woman's head covering as unimportant, but Calvin stands alone in regarding the silence of women in the church as a matter of custom rather than a matter of principle (see Douglass 1991:247). When discussing the tension between 1 Corinthians $11: 7$ and Galatians 3:28, he shows insight in the difference in context. Galatians 3:28 refers to the kingdom of God, whereas in Corinthians it is about the earthly dispensation. In this world male dominance is a social given.

Calvin's argument is more nuanced than Luther's direct connection between the subordination of women and the Fall - a view which had (and still has) dire consequences (cf Potter 1986:725-730). Together with the medical doctors of the Renaissance Calvin rejects Aristotle's views on female physiology. Women also contribute "seed" to procreation. According to Calvin's christological interpretation, the "perfect man" in Ephesians 4:13 need present no problem for women. Christ is the perfect man. All Christians, men and women, strive for this perfection. There is no difference. However, in spite of this view, Calvin - like Karl Barth later - does not make room for women in official positions. Calvin's reason is not a matter of anthropological principle. In this he differs from Luther who sees women's subordination as a natural state on account of the Fall (Douglass 1991:248; see Ruether 1991:269; cf 1975, 1983). Like Barth, Calvin bases his view on a "theology of creation" which then leads to a "divine moral law". Calvin explains the authority of a woman such as Deborah, as an extraordinary deed of God. Extraordinary deeds of God are not opposed to the natural order of human beings. Calvin considers the possibility that the subordination of women should not necessary keep them from positions of authority and teaching, since prophets and teachers also submit to kings and other rulers. The position of women is different, though, since women were "naturally born to be obedient". "After all, wise people have always rejected female rule as deplorable" (Calvin).

Though Calvin does not endorse the traditional argument of woman's inferior nature, his argument in the end also amounts to a degradation of female nature. Calvin finds support for his argument in common knowledge and common agreement. This is a sure sign of being caught up in institutionalisation. According to Calvin, 1 Corinthians 11:7 refers only to the 
domestic situation. In Genesis, on the other hand, it is about the glory of God which is carried in human nature. Human beings, male and female, carry the image of God in them. The man by himself represents less than full humanity.

On this point Calvin differs radically from Medieval theologians. For Calvin woman is also image of God, though only to a secondary degree (secundo gradu). Therefore the man is responsible for her and she is subordinate to him. When he discusses the concept of woman as "helpmeet", he regards her as lifelong partner and not only as a necessity for procreation. This "emancipatory" line of thought in Calvin's gender theology developed as he reworked the Institutes quite a few times. In his last edition just before his death this idea of woman as "second degree image of God" no longer appears and neither are there any references left to woman's inherent subordinate nature (Douglass 1991:249-251).

\section{THE ENLIGHTENMENT FAILURE TO ACHIEVE EMANCIPATION}

Though further developments in social philosophy did take place, the modern Protestant faith community still reflects the theologies of the Reformation. The historical Protestant view of Scripture made it impossible to cling to ideas of a bodiless state of the soul (Ruether 1991:269). Before the Fall there were two embodied people. Reformers also did not subscribe to the idea that "reason" and "rulership" were inherent to the image of God. During the Enlightenment the idea of an "original state" of humanity when people were equal, developed. Human societies departed from this original state and the result was injustice - privilege for some and subjugation for others. Revolutionary liberalism rejected the feudal system with its privileged aristocracy. The aim was to create a society similar to the original state. Redemption as the restoration of the image of God in people now became a social project. However, women were not included in this "human rights project". Reason and dominance were still exclusive to males. Slaves, children or males without property, were also not included. The patriarchal idea that the male as head of the household represented humanity and was the representative of his family, therefore simply continued. The Enlightenment did, however, provide the climate within which feminists could start campaigning for the inclusion of women as autonomous persons in civil rights. When slavery was abolished, civil rights extended to all adult males. Social trends increasingly moved towards individualism. People who had traditionally been dependent on a male head of the family, now claimed autonomous personhood and civil rights for themselves (see Ruether 1991:269-270). 
The reaction of $19^{\text {th }}$ century Romanticism to Enlightenment views was varied. Over against the liberal model of human nature as reason and moral will, Romanticism focuses on a variety of human types. People were classified according to race, social position and sex. The "opposite" nature of men and woman was emphasised. Men were seen as rational and active, whereas women were regarded as emotional and passive. As the public sphere became more secularised, religious piety and morality were increasingly left to women. Men were seen as more secular and therefore women's piety and morality were to help men. The female sex was seen as naturally more Chistlike: morally pure, long-suffering and patient, altruistic in their service to others. This could imply that women would now be the superior sex. However, their moral and spiritual purity would render them incapable of the rough tasks of power (see Ruether 1991:169-171). In its romantic form the dual nature anthropology led to the simultaneous subordination and glorification of the feminine. The mystique of the good mother, sister and wife, in effect isolated women from the public sphere and relegated them to the private sphere where they were to create a peaceful and safe environment for the men who had to go out into the cold and harsh world (see Coll 1994:74-75). Feminine virtues should be exercised in the sphere outside of history. "These notions of woman's 'sacred' nature, too pure and delicate for the male secular world, became a stock argument against allowing women rights in public society" (cf Douglass 1977).

During the Romantic period Friedrich Schleiermacher stands out as an exception to the rule. According to Marilyn Chapin Massey in her work, Feminine soul: The fate of an ideal (1985), Schleiermacher is an example of how women's experience falls victim to romanticising with the result that women are deprived of symmetrical interaction with men (see also Clark \& Richardson 1977:173-190). A Schleiermacher scholar, Dawn DeVries (1996:551), however, indicates that Massey's point of view is anachronistic, "imposing a definition of 'feminism' taken from the latter part of the twentieth century on texts written in the first decades of the nineteenth." According to Ruth Richardson (1991:182), Schleiermacher can rather be regarded as "a harbringer or forerunner of feminism". However, in Karl Barth's (1962:136158) discussion of Schleiermacher's ([1806] 1991) Christmas Eve Dialogue, he shows that Schleiermacher's theology goes "wrong" exactly where his ideas on religious experience and his view on women come together.

Schleiermacher's view on women can be seen in a variety of his works (see Thandeka 2005:287-306; Crouter 2005:109-117). One of these is the Christmas Eve: Dialogue on the incarnation, written in 1806. In this work the tension between the question of the historical Jesus and the conventional 
dogma of incarnation is discussed in a fictive family conversation on Christmas Eve. The characters in the story represent either the clinical rationalism of liberalism or rigid orthodoxy. The author-theologian does not subscribe to either of these. In this work, Schleiermacher's concept of religion as a feeling of dependence can be understood from a historical-critical perspective as well as from the context of the church. According to Keith Clements (1987:195) this work is "one of the most humanly charming pieces of serious theology ever written, as it vividly portrays young and old, men and women, skeptic and pietistic, enjoying music and conversation and sharing their thoughts on the significance of the joy of the Christmas season". Drucilla Richardson (1991:133-164), in her study of this and other of Schleiermacher's works (among others Confidential letters on Friedrich Schlegel's Lucinde [1800] in which he responds to the ideas of his Berlin artist friend, the poet Friedrich Schlegel - see Clements 1987:19-22) points out that Schleiermacher used the term Anschauung as a consciously male Geschlechtscharakter and Gefühl as a consciously female one. In doing so, Schleiermacher redefines $18^{\text {th }}$ century (actually the entire previous agrarian period) ethics of honour (male characteristic) and shame/virtue (Schamhaftigkeit - a female characteristic). In his "Essay on the sense of shame" (Versuch über die Schamhaftigkeit) in his Confidential letters concerning Schlegel's Lucinde, Schleiermacher interprets the concept Schamhaftigkeit as "respect" in the sense of respect for the freedom and sensitivity for the fragility of all people, including male and female persons, in their interaction with one another (cf Crouter 2005:110-111).

Schleiermacher was known for his intellectual friendships, also with women, among them his sister, Charlotte von Kathen, the married Jewish woman Henriette Herz and Eleonore Grunow, the wife of a Berlin pastor (see Clements 1987:21). In a letter to Leonore in 1802, Schleiermacher writes: "for it is through the knowledge of the feminine heart and mind that I have learnt to know what real worth is" (Clements 1987:21). To his sister Charlotte he writes: "if ever I find myself sportively indulging in an impossible wish, it is, that I were a woman". Clements (1987:22) comments as follows:

The reason Schleiermacher gives for this fantasy, however, should be noted. It is the opportunity, as he sees it, for women to retain inner feelings of love and imagination as compared with men who are so quickly lost and occupied in activity. Protestant machismo ("Rise up, o men of God!") has long been embarrassed by feminine humanity, and perhaps, Schleiermacher has an important speech to deliver in this direction as well. 
After the characteristic optimism about humanity of the Aufklärung, liberalism and Romanticism, disillusioned German Protestant theologians after the Second World War revert back to Reformation teachings on the radical sinfulness of human beings. They were also influenced by the social philosophy of the time, among others the "I-You" concept of Martin Buber ([1953] 1988, 1958, 1984). Buber distinguishes between subject-subject and subject-object relationships. The latter is dehumanising, whereas respect is expressed by means of subject-subject relationships. Buber's model bridges the gap between individualism and society which constituted a problem in European thinking. Subject-subject relationships provide a model with which to bring autonomy and community together. This perspective of Buber's influenced theological views on the image of God (see Ruether 1991:271). "Neoorthodox" Protestant theologians approach Genesis 1:27 from a specific point of view. This "dogmatic disparity" of Karl Barth's is the epitome of asymmetrical theological thought.

Over against the Roman Catholic idea that the image of God had been distorted by the Fall, Neoorthodox Protestant theologians regard the image of God in human beings as totally lost. People cannot reach God by means of anything from the natural order. There is no salvation in humanity. Salvation can come only from God. A sharp distinction is made between human nature and divine nature. Human beings in no way share in divine nature. Analogia entis does not feature in this theology. A distinction is also made between nature and history, between human beings and animals. What makes human beings unique and "God-like" in a way, is their ability to form relationships with other subjects. The image of God in human beings is defined as analogia relationis in distinction to the Roman Catholic analogia entis. Patriarchal relationships of male to female, reason/soul to body and the dominant to the subordinate are essentially subject-object relations (Ruether 1991:271).

\section{GENDER BIAS IN REFORMED THEOLOGY}

It is interesting to see what the fruit of all this was in the theologies of some prominent Reformed theologians. Dietrich Bonhoeffer takes the idea of the image of God as analogia relationis further. He puts it as follows (Bonhoeffer [1937] 1959:37): "The likeness, the analogy of man to God, is not analogia entis but analogia relationis ... The relation of creature with creature is a Godgiven relation because it exists in freedom and freedom originates from God". It is a unique characteristic of human beings that they exist in relationships. God created humans free from the determinism of nature and free to relate to one another. The freedom disappeared with the Fall, but was restored in Christ. Bonhoeffer (1959:33-38, 76) does not, however, apply this argument to 
the relationships between the sexes. He refers solely to the freedom to relate with the "brother". When he discussed the Fall, it becomes clear that he still regards women as "weaker" than men. This is the reason why the serpent first approached the woman.

Emil Brunner also discusses "image of God" as an analogia relationis. Brunner, like Bonhoeffer, is aware of the problem of the equality of subjects addressed by Buber's I-Thou concept. He also uses the term "brother" for the other. Similar to the model of his day, his typifies the relationship between the sexes is one of complementarity. He concedes that women have a greater right to autonomy and the development of their personalities than has traditionally been allowed. However, according to him, women should remain in their traditional roles in their relationships with men. "True women" who understand their female nature, should take the role of supporting their husbands upon themselves voluntarily, in order for men to be able to be fully masculine (see Brunner 1952:55-68; [1957] 1965:373-380).

\section{BARTH'S COVENANTAL BASIS}

Karl Barth sees the relationship between human beings and God as covenantal. He interprets the image of God as analogia relationis in such a way that the God-human hierarchy becomes the analogy for male-female relationships (see Micks 1982:9-10). From a Reformed and non-dialectical perspective, Berkouwer (1962:72-73) agrees with Barth's emphasis on the importance of male and female in the history of creation, but criticises Barth's conclusion that relationship is the content of "image of God". For Barth the relationship between God and human beings entails that God speaks and people react in faith. God remains the transcendent Subject, even though human beings are also subject. Because of sinful human nature human beings cannot react to God of their own accord. Christ does this for them (see Buitendag 1986:688). The hierarchical order of male and female in the family and in society is not about the intrinsic superiority of men and inferiority of women. However, men and women should assume their place and roles within God's order and obey God's will. Josephine Ford (1984) points out Barth's lack of a vision of how true subject-subject interaction between men and women can be possible. The Protestant theologian, Jürgen Moltmann (1985), attempts to save the concept of "image of God" as analogia relationis while trying to get around Barth's hierarchical ordering of male and female as "A" and "B" (cf Jewett 1975:33-43).

According to Ruether (1991:274) the problem with the concept analogia relationis is that the relationship between male and female is bound to the relationship between God and people by means of analogy. The relationship 
between God and human beings can never be an egalitarian and mutual relationship. This is why the modern Protestant concept of "image of God" as analogia relationis does not succeed in fully including woman in the image of God. The basic tendency in Christian tradition to make man like God, but woman like creation, is simply perpetuated. Christian feminist anthropology, on the other hand, sees Genesis 1:27 as an egalitarian text in which woman and man represent the image of God. Galatians 3:28 is mostly viewed as a parallel interpretation. Such a reading could however be criticised as anachronistic.

Philosophical and theological ideas influence the everyday lives of people. Some of the above ideas could have the potential to bring about positive change for women. An example of this is the liberal view that all human beings have the same nature. Human nature is defined as reasonable and moral. However, the roots of this definition of human nature can be traced to the classical Christian tradition in which "reason" and "dominance" over lower domains were allocated to men. Women's ability to reason and be moral was deemed inferior to that of men. For this reason women were not entrusted with leadership positions. At the beginning of the twentieth century when women gained access to universities, it was feared that the development of reason in women might be detrimental to their reproductive abilities (see Coll 1994:75; cf Hall 1916).

The patriarchal roots of the liberal tradition became even clearer when civil rights were denied women. The male head of the family was still seen as the representative of "human nature" who represents those dependent on him. Later, the inclusion of women in civil rights was still based on a split between the private sphere of the house and the public sphere. Women's equality before the law now obscured their continued economic dependence in the home and work place. Liberal egalitarian strategy was based on assimilating women in a male model of humanity (see Ruether 1991:275). It did not provide a basis for true equality in practice - neither in the family, nor in the work place. The Romantic notion of "complementarity" views masculinity and femininity as opposite natures with different unique characteristics. Female qualities, for instance, include piety and an altruistic morality which implies that women would naturally be more "Christ-like" than men. According to Ruether (1991:276) this view relegates women to an other-worldly powerlessness.

In all of this philosophical and theological argumentation it was men talking to one another about women. Women still did not have the prerogative to define themselves, to articulate their own understanding of the Bible and of their place in society. The anthropology of two natures defined women and 
men according to the norms and worldview of a bygone era. These norms and views were often equated with "God's will" and therefore regarded as unchanging. "Dualistic thinking strives to maintain the status quo as the natural order fixed by creation - as if what exists is from on high" (Coll 1994:76). Dualistic thinking leads to an easy acceptance of patriarchal systems and the dominance of powerful men over less powerful men and women. It is also seen as "natural", "how things ought to be" and "God-given". The roles attributed to men and women by culture, are seen as part of God's eternal plan.

Social and psychological characteristics of the sexes are accepted as God-given and therefore unchangeable. Dualistic anthropology defines women according to their procreative potential. Women's physiology determines their humanity. Every facet of their lives is determined by the potential ability to bear a child. Even women who are not mothers, are defined in terms of motherhood. According to the traditional view, women were created to be mothers, whereas men were not created to be fathers (see Coll 1994:76-77). This dualistic model functions on two levels. On the one level, women as inferior beings are the helpers of men and therefore it is assumed that they will serve men and in turn receive protection from the evils of this world. On the other level, women are seen as complementary to men. They provide a female dimension that men do not have. Women are caring and have nurturing qualities which they contribute to the public sphere. Women are therefore not able to function in the roles that have traditionally been the prerogative of men. Men and women are both limited to specific gifts, abilities and behaviours by such a view (cf Coll 1994:75).

\section{A FEMINIST ALTERNATIVE}

The objective of the feminist movement was to bring women to voice.

Victorian and contemporary feminist movements reacted differently to dualistic anthropology. The reformed approach saw women in their roles as wife and mother as morally higher than males. Women were to reform these "fallen" males from the violence, injustice and moral corruption that permeate the male world (see Gifford:1981). The separatist approach viewed male violence and injustice as beyond redemption. Men were the inferior sex. They displayed a lack of full humanity visible in their inability to love, care for others and sustain mutual relationships. Men were seen as violent, heartless egotists by nature. Women should therefore separate themselves from the male world and endeavour to create a new and better world (see Ruether 1991:276). Modern separatists regard maleness and the patriarchal system as the origin of all evil. They want to create a community of women. The most renowned 


\section{Karl Barth's male-female order: A kingpin of dogmatic disparity}

exponent of this view is Mary Daly (1984:370) who explains it as follows: "(S)eparatism is an essential aspect of gynophilic communication, for it separates a woman from the causes of fragmentation - the obstacles, internal and external - which separates her from the flow of integrity within her self".

Rosemary Ruether $(1975,1983,1991)$ is known for her critique of this view. According to her, the feminist movement wants to move away from dualism and move towards a "one nature" anthropology. The difference between the two views is articulated as follows by Coll (1994:70): "Dual-nature anthropology suggests that women and men are of different natures determined by God and that these different natures determine what is appropriate for each sex ... (S)ingle-nature theory ... holds that most differences between women and men are culturally defined and therefore open to change". The Biblical basis of single-nature theory is Genesis 1:27. According to this view there is but one way of being human - not a male way and a female way. There are no precast roles or functions for the different sexes. The only real difference is biological. According to the dualistic view, personality and psychological traits are described according to opposite categories: self-motivated behaviour, independence, courage and rationality as masculine, and softness, sentimentality and generativity as feminine. Modern research has shown, however, that much of what had been termed "masculine" of "feminine" is culturally constructed (cf Mead 1939).

Coll $(1994: 80,81)$, however, is critical of the single-nature theory because it provides men with more opportunities to develop as human beings. Women who have had fewer opportunities, tend to just learn to survive within a male system which leaves little or no room for the value of women, their experiences and histories. Though sounding fine in theory, in practice it could simply mean that the system of maleness functioning as norm for humanity, is perpetuated. This theory also does not take biological differences such as hormones, for instance, into account. These do contribute to the specific experience of men and women in the world. What "woman" means exactly, still remains unknown, since what is at hand, is a long tradition of male constructs from a male perspective. Only fairly recently a growing protest against this has developed.

An androgynous model sees both sexes as having the qualities previously only ascribed to one sex. It suggests that men and women have a set of common characteristics. The advantages of such a model is that "... women who are ambitious, initiating and assertive would no longer be perceived as overly masculine and lacking femininity. Nor would men who are gentle, relational, and aesthetic feel that they must make up for these qualities by adopting a macho attitude. Women and men alike might be able to 
perceive themselves as human beings who sometimes act independently as agents and who sometimes act communally" (Coll 1994:81). In general the feminist movement has chosen for an extended single-nature anthropology. Ruether (1991:276) puts it as follows:

(F)eminism has taken its stand on an expanded unitary view of human nature, possessed fully and equally by both men and women. The expanded unitary view brings into the definition of humanness the qualities of sensual and intuitive feeling, altruism and care, along with the capacities for reason and moral will. It seeks to synthesize the two sides of the complementary model in one androgynous humanness, possessed equally by women and men.

The feminist movement rejects both the view of the male as representative principle of human nature and the dichotomy of complementarity. Both are based on a dualistic anthropology. In modern feminist hermeneutics the interpretation of man and woman as image of God has taken a different course. In the first place it is accepted that all interpretations of "image of God" constructed by human beings, are human projections. "The definition of God as patriarchal male is presumed to be a projection by patriarchal males of their own self-image and roles, in relation to women and lower nature, upon God. Thus it is not 'man' who is made in God's image, but God who has been made in man's image" (Ruether 1991:277). God is in actual fact beyond the reach of human words, images and concepts - people can only speak metaphorically about God and can only partially express God (cf McFague [1982] 1985, 1987). Any attempt to image God should be done very carefully, humbly and with the awareness of the limitations and provisional character of such an effort. There should furthermore be a sensitivity as to how this provisional imaging of God, which originates in a specific context and from a specific perspective, affects those outside of that context and perspective whether others are hurt or demeaned in the process.

\section{FINDINGS}

In order for human beings to create a "humane" society, critical theologians find it important to remain suspicious of a dehumanising status quo. In order to open up the possibility of authentic humanity for all people it is necessary to be aware that constructs and social patterns are human creations, not Godgiven structures. Therefore they have the potential to do harm or be evil. Leroy Howe (1995:23) puts it as follows: 
Central to a Christian understanding of human existence is the conviction that God is at work re-creating the whole of humanity as a single family whose members share a common calling to care for the created order. But our sense of partnership wanes with the failure to restrain our impulses to dominate, and solidarity with all human beings is everywhere eclipsed by oppression and enslavement. Nevertheless, we continue to yearn for a truly caring society as the harvest of a genuinely meaningful historical process.

The possibility to harm people should be critically exposed. People should be aware and make others aware of the harmful potential of what is often regarded as "simply how things are". Awareness can lead to change. The aim is that all people can enjoy an authentic life before God. The "old person" is the one who existed outside of God's grace. This old person has been put away and the "new person" is the one who knows Christ, is instructed by him and lives in righteousness and holiness (Eph 4:17-24). It is in this new life that the image of God manifests. This happens in the lives of individuals but also in the life of the community (cf Eph 2:17-22). Barriers are removed in the new community and "there is no difference any more between Greek and Jew, circumcised and uncircumcised, barbarian and Scythian, slave and free, but Christ is all, and all are in Christ" (Col 3:10). This and Galatians 3:28 do not mean that difference disappears. The focus is, however, on the newness of the community, not on the differences.

The newness means that humanity has returned to its true nature one from which it had been alienated. Persons are no longer a threat to one another, but live together in peace and harmony. Differences still exist, but, "no matter how deep-seated the differences between men may be, in Christ the tension and convulsiveness vanish before the new nature" Berkhouwer (1962:99). Therefore, this image of God as it manifests in the new person, cannot just be an "analogy", but is the fullness of a life lived in a new relationship with God. The renewal of the image of God in human beings is not about analogy, but about conformity: Christ becoming visible in the life of individuals and the community. They become Christ-like.

Berkhouwer (1962:100) criticises Barth in that one cannot place analogia relationis over against the older analogia entis when discussing the image of God in human beings. Though he agrees with Barth's criticism of the analogia entis, he does not find that one is then compelled to choose analogia relationis. His reason is the following: "For Scripture does not deal with a 'relation', but with a relation as it becomes visible in and through the reality of salvation .... [W]e can speak of this reality, of the newness of life, in the most concrete and 'everyday' sense. The believer is called, in this life, to the 
imitation of God." Being renewed in the image of God means becoming "like" God. To paraphrase texts from Scripture (from Gl 5:22 and Lk 6:35-37): "Be kind to one another, tender-hearted, mutually forgiving, even as God has in Christ forgiven you." Paul calls upon the faith community to "pattern yourselves after God as [God's] loved children, and live in loving ways, nothing but the keeping of the commandments of God" (1 Cor 7:19). This way of life, the new life of becoming more God-like, is what Jesus said, according to Matthew, when he summoned the believers to: "Be perfect, just as your Father in heaven is perfect" (Matt 5:48).

Rather than analogia entis, this new way of being "like God" can be called analogia amoris - the analogy of love, with its basis in the emptying of himself of Jesus who became like human beings. Herein lies the renewal of the image of God, according to Berkhouwer (1962:116-117). He sees the image of God in human beings as something which was lost and has been found. The image of God concerns the whole human being as she or he exists in this world on their way to a future, as they exist as God's children in God's likeness.

Yet, more than Berkhouwer in his criticism of Barth, the feminist attempt to reconstruct both male and female as equal bearers of God's image searches for a fair anthropological basis. Images of God that are constructed, should provide space for the full realisation of human potential for women and men. The question should always be: which human projections about God lead to injustice and a diminished humanity for some and which projections contribute to the full humanity of all people (Ruether 1991:277). Constructs such as theological and anthropological theories are not innocent or harmless. History has shown how they have functioned to influence social structures on the one hand, and on the other hand to legitimate social structures. Culture forms our humanity. People inherit the norms and ways of thinking of their society and internalise them. They become part of how people define themselves. Often people are unaware of the negative aspects which are inadvertently absorbed. In the case of women in particular, the process of the internalisation of negative messages goes as follows (cf Mulder 1997:9-33):

Es scheint, daß alle üblichen Vorstellungen über die Frau als das Negative vom Mann oder als seine Gehilfin: "Mutter von ...", "Frau von ...", "Tochter von ...", "Mätresse von ..." mit all ihren entsprechenden sozialen Realitäten, die Frauen produziert und reproduziert haben, gebildet wurden, weil dies die Modelle waren, nach denen sie ihre Identität geformt haben.

(Mulder 1996:72) 
Not only women are hurt when systems dehumanise people. A dehumanising system will affect those with less and those with more power, only in different ways: "When the systems operative in a culture are demeaning and dehumanizing, a vicious circle is set in motion in which women and men are prevented from developing the full humanity to which they are called. At the same time fractured humanity is incapable of creating a society that is truly human" (Coll 1994:82).

\section{Works consulted}

Barth, K 1932-1969. Die Kirchliche Dogmatik. München: Chr Kaiser Verlag.

Barth, K 1934-1964. Church Dogmatics, 4 volumes, tr by G W Bromiley et al. Edinburgh: T\& T Clark.

Barth, K [1952] 1973. Protestant theology in the nineteenth century: Its background \& history, tr by B Cozens \& J Bowden. Valley Forge, PA: Judson.

Barth, K 1978. Concluding unscientific postscript on Schleiermacher. Studies in Religion/Sciences Religieuses 7(2), 117-135.

Barth, K [1923-1924] 1982. The theology of Schleiermacher: Lectures at Göttingen, Winter Semester of 1923-1924, edited by D Ritschl. Grand Rapids, MI: Eerdmans.

Bavinck, H 1906-1910. Gereformeerde dogmatiek, 3 dele. Kampen: Kok.

Berkouwer, G C 1962. Man: The image of God. Grand Rapids, MI: Eerdmans.

Bonhoeffer, D [1937] 1959. Creation and fall: A theological interpretation of Genesis 1-3. London: SCM.

Bird, $P$ 1991. A sexual differentiation and divine image in the Genesis creation texts, in Børresen, K E. Image of God and gender models in Judaeo-Christian tradition. Oslo: Solum Forlag.

Børresen, K E 1981. Subordination and equivalence: The nature and role of woman in Augustine and Thomas Aquinas, tr by $\mathrm{C} \mathrm{H}$ Talbot. Washington, DC: University of America Press.

Børresen, K E 1991a. God's image, is woman excluded?: Medieval interpretation of Genesis 1:27 and I Cor 11:7, in Børresen, K E (ed), Image of God and gender models in Judaeo-Christian tradition. Oslo: Solum Forlag.

Børresen, K E 1991b. God's image, man's image? Patristic interpretation of Genesis 1:27 and I Cor 11:7, in Børresen, K E (ed), Image of God and gender models in Judaeo-Christian tradition. Oslo: Solum Forlag.

Bouwsma, W J 1988. John Calvin: A sixteenth century portrait. New York: Oxford University Press.

Bratsiotis, P 1951. Genesis 1:26 in der orthodoxen Theologie. Evangelische Theologie 11, 289-297.

Bromiley, G W [1936] 1975. Translation of Karl Barth's Church Dogmatics. Edinburgh: $T \&$ T Clark.

Brunner, E 1952. The Christian doctrine of creation and redemption. Philadelphia, PA: Westminster.

Brunner, E 1957. The divine imperative. Philadelphia, PA: Westminster. 
Brunner, E [1963] 1984.Wahrheit als Begegnung. Sechs Vorlesungen über das christliche Wahrheitsverständnis. 3. Auflage. Zürich: Theologischer Verlag.

Brunner, E [1957] 1965. Die Mensch im Widerspruch: Die christliche Lehre vom waren und vom wirklichen Menschen. 4. unveranderte Auflage. Zürich: Zwingli.

Buber, M [1953] 1988. Eclipse of God: Studies in the relation between religion and philosophy, with an introduction by Robert M Seltzer. Atlantic Highlands, NJ: Humanities Press International.

Buber, M 1958. Moses: The revelation and the covenant. New York: Harper \& Row.

Buber, M 1984. Das dialogische Prinzip: Ich und Du. Zwiesprache. Die Frage an den Einzelnen. Elemente des Zwischenmenschlichen zur Geschichte des dialogischen Prinzips. Heidelberg: Verlag Lambert Schneider. (Lambert Schneider Tassenbücher.)

Buitendag, J 1986. Die skepping as gelykenis: 'n Beoordeling van die skeppingsleer van Karl Barth in die lig van die appèl van die ekologiese krisis. HTS 42(4), 674-695.

Buitendag, J 2007. Marriage in the theology of Martin Luther - worldly yet sacred: An option between secularism and clericalism. HTS 63(2), 455-461.

Bulgakov, S 1937. Die Christlike Anthropologie. Kirche, Staat und Mensch: Russischorthodoxe Studiën, 223.

Calvin, J [1962]. Institutes of the Christian religion, I, XV, 3, a new translation by H Beveridge. London: James Clarke.

Calvin, J [1948], Commentaries on the First Book of Moses called Genesis, translated from Latin and compared with the French edition by J King. Grand Rapids, MI: Eerdmans.

Coll, R A 1994. Christianity and feminism in conversation. Mystic, CT: Twenty-Third Publications.

Clark, E \& Richardson, H 1977. Schleiermacher and Baader: Individuality and androgyny, in Clark, E \& Richardson, $\mathrm{H}$ (eds), Women and religion: $A$ feminist sourcebook of Christian thought, 173-190. New York: Harper \& Row.

Clements, K 1987. Friedrich Schleiermacher: Pioneer of modern theology. London: Collins. (The Making of Modern Theology. 19th and 20th Century Theological Texts.)

Crouter, R 2005. Friedrich Schleiermacher: Between Enlightenment and Romanticism. Cambridge: Cambridge University Press.

Daly, M 1984. Pure lust: Elemental feminist philosophy. Boston, MA: Beacon.

DeVries, D 1996. Review article, Richardson, R D 1991, The role of women in the life and thought of the early Schleiermacher (1768-1806): An historical overview, in Epp, E J (ed), Critical review of books in religion, Vol 7 (1994), 551-553.

Atlanta, GA: Scholars Press.

Douglass, J D 1985. Women, freedom, and Calvin. Philadelphia, PA: Westminster.

Douglass, J D 1991. The image of God in women as seen by Luther and Calvin, in Børresen, K E (ed), Image of God and gender models in Judaeo-Christian tradition. Oslo: Solum Forlag.

Dawson, R D 2007. The resurrection in Karl Barth. Hampshire: Ashgate. (Barth studies.)

Dreyer, Y 2007. Karl Barth's male-female order as asymmetrical "theoethics". HTS 63(4), 1493-1521. 
Ebeling, G 1971. Lutherstudien, Band I. Tübingen: Mohr Siebeck.

Eichrodt, W [1939] 1961. Theology of the Old Testament, Vol 1, tr by J A Baker. London: SCM.

Eichrodt, W [1939] 1967. Theology of the Old Testament, vol 2, tr by J A Baker. London: SCM.

Eichrodt, W [1939] 1967. Theology of the Old Testament, 2 volumes, tr by J A Baker. Philadelphia, PA: Westminster.

Ford, J C 1984. Toward an anthropology of mutuality: A critique of Karl Barth's doctrine of the male-female order as $A$ and $B$ with a comparison of the panentheistic theology of Jurgen Moltmann. Unpublished PhD dissertation. Northwestern University, Ann Arbor, Michigan, USA.

Gifford, C 1981. Women in social reform movements, in Ruether, R R \& Keller, R (eds), Women and religion in America: The nineteenth century, 294-340. San Francisco, CA: Harper \& Row.

Görgemanns, H \& Karpp, H (eds) 1976. Origenes vier Bücher von den Prinzipen. Darmstadt: Wissenschaftliche Buchgesellschaft.

Hall, W C 1916. Sexual knowledge. Philadelphia, PA: John C Winston.

Hart, T 2000. Revelation, in Webster, J (ed), The Cambridge Companion to Karl Barth. Cambridge: Cambridge University Press.

Howe, L T 1995. The image of God: A theology for pastoral care and counseling. Nashville, TN: Abingdon.

Jewett, P K 1975. Man as male and female: $A$ study in sexual relations from a theological point of view. Grand Rapids, MI: Eerdmans.

Köstenberger, A J 1997. Ascertaining women's God-ordained roles: An interpretation of I Timothy 2:15. Bulletin for Biblical Research 7, 107-144.

Luther, M [1522] [1963] 1990. Vorrede auf die Episteln S. Jacobi und Judae. $A D B 7=$ Luther Deutsch. Die Werke Luthers in Auswahl, Bd. 5: Die Schriftauslegung, hrsg von Kurt Aland. 4. Auflage. Göttingen: Vandenhoeck und Ruprecht. (UTB 1656.)

Massey, M C 1985. Feminine soul: The fate of an ideal. Boston, MA: Beacon.

McCormack, B L 1998. Revelation and history in transfoundationalist perpective: Karl Barth's theological epistemology in conversation with a Schleiermacherian tradition. Journal of Religion 78, 18-37.

McFague, S [1982] 1985. Metaphorical theology: Models of God in religious language. Philadelphia, PA: Fortress.

McFague, S 1987. Models of God: Theology for an ecological, nuclear age. Philadelphia, PA: Fortress.

McKelway, A J 1979. The concept of subordination in Barth's special ethics. Scottish Journal of Theology 32(4), 345-357.

Mead, M 1939. Sex and temperament in three primitive societies. New York: Morrow. Micks, M H 1982. Our search for identity: Humanity in the image of God. Philadelphia, PA: Fortress.

Moltmann, J 1985. God in creation. San Francisco, CA: Harper \& Row.

Mulder, A C 1996. Überlegungen zur "imago Dei": Minimalisierung oder Maximalisierung der Differenz zwichen den Geschlechtern, in Günter, A (Hrsg), Feministische Theologie und postmodernes Denken: Zur theologischen Relevanz der Geschlechterdifferenz. Stuttgart: Kohlhammer. 
Mulder, A C 1997. Thinking about the 'imago dei' - minimalizing of maximalizing the difference between the sexes: A critical reading of Rosemary Radford Ruether's anthropology through the lens of Luce Irigaray's thought. Feminist Theology 14, 9-33.

Oberman, H A 1963. The harvest of medieval theology: Gabriel Biel and late Medieval nominalism. Cambridge, MA: Harvard University Press.

Potter, M 1986. Gender equality and gender hierarchy in Calvin's theology. Signs 1, 725-739.

Richardson, R D 1991. The role of women in the life and thought of the early Schleiermacher (1768-1806): An historical overview. Lewiston, NY: Edwin Mellen. (Schleiermacher Studies and Translations 7.)

Ruether R R 1975. New woman/New earth: Sexist ideologies and human liberation. New York: Seabury.

Ruether, R R 1983. Sexism and God-talk: Toward a feminist theology. Boston, MA: Beacon.

Ruether, R R 1991. Imago Dei, Christian tradition and feminist hermeneutics, in Børresen, K E (ed), Image of God and gender models in Judaeo-Christian tradition. Oslo: Solum Forlag.

Schleiermacher, F D E [1806] 1991. Christmas eve, tr by T N Tice. Lewiston, NY: Edwin Mellen Press. (Schlieiermacher Studies and Translations 4.)

Thandeka 2005. Schleiermacher, feminism, and liberation theologies: A key, in Mariňa, J (ed), The Cambridge companion to Friedrich Schleiermacher, 287306. Cambridge: Cambridge University Press.

Verkhowsky, S 1951. Die Lehre von Menschen im Lichte der orthodoxen Theologie. Evangelische Theologie 11, 321-323.

Von Rad, G 1964. s v eikסn, in Kittel, G (ed), Theological Dictionary of the New Testament, vol II, 381-383. Grand Rapids, MI: Eerdmans.

Von Rad, G [1953] 1972. Das erste Buch Mose, Genesis. Göttingen: Vandenhoeck und Ruprecht, (Das Alte Testament Deutsch 2-4.)

Von Rad, G [1961] 1972. Genesis: A commentary, tr by J H Marks, rev edition. Text revised on the basis of the ninth German edition. London: SCM. (The Old Testament Library.)

Wallace, M I [1990] 1995. The second naiveté: Barth, Ricoeur, and the New Yale Theology. Macon, GA: Mercer University Press. (Studies in American Biblical Hermenutics 6.)

Zimmerli, W [1907] 1967. 1. Mose 1-11: Die Urgeschichte. Zürich: Zwingli. 